\title{
PELATIHAN PEMBUATAN VIDEO PEMBELAJARAN UNTUK GURU MA AL- ISTIQOMAH NW BEDUS
}

\author{
Dwi Pangga1), Sukainil Ahzan ${ }^{1)}$, Syifaul Gummah"1), Saiful Prayogi1) \\ 1)Program Studi Pendidikan Fisika, FPMIPA, Universitas Pendidikan Mandalika, Mataram, Indonesia \\ Corresponding author : Dwi Pangga \\ E-mail: dwipangga@ikipmataram.ac.id
}

\section{Diterima 9 Desember 2019, Disetujui 5 April 2020}

\begin{abstract}
ABSTRAK
Tujuan umum kegiatan pengabdian masyarakat ini adalah menstranfer ilmu berupa cara pembuatan video pembelajaran pada guru MA Al-Istiqomah NW Bedus. Diharapkan hasil dari kegiatan ini sebagai langkah awal terjalinnya kerjasama antara kampus IKIP dengan pihak mitra secara berkelanjutan dan tidak terpisahkan. Pengabdian ini dilaksanakan di MA Al-Istiqomah NW Bedus, Desa Bangket Parak, Kecamatan Pujut, Lombok Tengah, dengan sasaran kegiatan adalah guru-guru sekolah sebanyak 20 orang. Pelaksanaan kegiatan dilaksanakan selama 6 (enam) bulan meliputi survei lokasi, diskusi penentuan jadwal kegiatan dengan pihak sekolah (mitra), sosialisasi kegiatan kepada calon target binaan, pelatihan pembuatan media, monitoring, dan evaluasi kegiatan. Indikator keberhasilan kegiatan terukur> 90\% kehadiran peserta datang tepat waktu dan berada dalam ruangan hingga kegiatan berakhir. Respon kebermanfaatan kegiatan pelatihan meliputi sebesar $85,0 \%$ (kategori sangat bagus) dan $15,0 \%$ berkategori cukup bagus; dan tingkat motivasi menjadi guru modern sebesar $80,0 \%$ tertarik dan $20,0 \%$ berkategori cukup.
\end{abstract}

Kata Kunci: pelatihan; video; media pembelajaran.

\begin{abstract}
The general objective of this community service activity is to transfer knowledge in the form of making instructional video media for MA Al-Istiqomah Bedus teachers. It is expected that the results of this activity will be the first step towards establishing cooperation between the IKIP campus and partners in an ongoing and inseparable way. This dedication was carried out at MA Al-Istiqomah NW Bedus, Bangket Parak Village, Pujut District, Central Lombok, with the aim of the activity being 20 school teachers. The implementation of the activities carried out for 1 (one) month includes a location survey, discussion of determining the schedule of activities with the school (partners), socialization of activities to the target target, training in media development, monitoring, and evaluation of activities. Measured indicators of success of activities $>90 \%$ attendance of participants arrive on time and stay indoors until the activity ends. The response of the usefulness of the training activities covered $85.0 \%$ (very good category) and $15.0 \%$ was quite good; and the motivation level to become a modern teacher is $80.0 \%$ interested and $20.0 \%$ is in the sufficient category.
\end{abstract}

Keywords: training; video; learning media.

\section{PENDAHULUAN}

MA Al-Istiqomah NW Bedus merupakan salah satu madrasah yang berada di bawah naungan Yayasan Bina Warga. Gedung MA ini berada dalam satu lokasi/kawasan dengan gedung MI, dan MTs., yang berdiri pada lahan seluas 1 hektar lebih. Siswa MA Al-Istiqomah NW Bedus, sebagian besar berasal dari lulusan MTs. Al-Istiqomah NW Bedus yang langsung melanjutkan studinya di tempat yang sama. Sedangkan sebagian besar lainnya berasal dari siswa/siswi dari luar Desa Bangket Parak, seperti Desa Teruwai, Desa Kidang, dan Desa Pengengat.
$80 \%$ siswa/siswi MA Al-Istiqomah NW Bedus berasal dari keluarga ekonomi menengah ke bawah, yang pekerjaan orang tuanya bertani. Hal tersebut menyebabkan siswa/ siswinya hidup sangat sederhana dan bersahaja, serta terjauh dari glamor kehidupan kota, sehingga mereka sangat menjaga kesopanan dan nilai-nilai luhur/tradisi penduduk setempat. Salah satu nilai positif yang sangat membedakan dengan sekolah lainnya yaitu kepatuhan mereka pada guru/ustad, yang sudah terbina sejak mereka masih MI/MTs.

MA Al-Istiqomah NW Bedus berada di wilayah Desa Bangket Parak, Kecamatan Pujut, Kabupaten Lombok Tengah. Desa 
Bangket Parak sebelah utara berbatasan dengan Desa Marong, sebelah Timur berbatasan dengan Desa Kidang, sebelah selatan berbatasan dengan Desa Pengengat, dan sebelah barat berbatasan dengan Desa Teruwai, seperti terlihat pada Gambar 01. Pada gambar terlihat bahwa jarak antara kantor Desa Bangket Parak skitar $1 \mathrm{~km}$. Sedangkan jarak dari MA Al-Istiqomah NW Bedus hingga kota Mataram mencapai sekitar $45 \mathrm{~km}$ ditempuh melalui by pass BIL dan skitar $56 \mathrm{~km}$ ditempuh melalui kota Praya.

Berada di wilayah pedesaan memberikan nilai lebih dalam perkembangan siswa/siswi MA Al-Istiqomah NW Bedus karena pengaruh tradisi/adat kebiasan masih sangat kuat. Hal tersebut menyebabkan penampilan siswa dari segi kesopanan dan norma agama sangat terjaga. Namun disatu sisi, kemajuan IImu pengetahuan dan teknologi serta peningkatan daya saing dan kompetensi siswanya masih tergolong rendah. Rendahnya kompensi siswa tersebut selain karena faktor lingkungan, juga dipengaruhi oleh faktor tenaga pendidik (guru).

Sebagai sekolah berlatar belakang agama serta guru-gurunya sebagian besar berlatar pendidikan agama juga menyebabkan penguasaan mereka terhadap pemanfaatan IT dalam pembelajaran masih rendah. Hanya sebagian kecil dari mereka yang menguasai/mampu memanfaatkan IT dalam proses pembelajaran. Hal tersebut menyebabkan rendahnya daya serap serta penguasaan pelajaran yang mereka terima, terutama yang berkaitan dengan pelajaranpelajaran umum, karena kurangnya motivasi mereka ketika mengikuti pembelajaran. Kurangnya motivasi siswa ketika mengikuti pembelajaran di kelas antara lain dipengaruhi oleh:

1. Masih monutonnya sistem pembelajaran, dimana guru sangat jarang memanfaatkan media pembelajaran dalam proses pembelajaran, sehingga siswa sering jenuh ketika mengikuti proses pembelajaran terutama pelajaran-pelajaran yang bersifat umum.

2. Masih minimnya sarana/alat laboratorium untuk pelajaran-pelajaran yang harusnya menggunakan lab, dan gurunya masih belum mampu memaksimalkan kearifan lokal yang tersedia serta mengembangkan pembelajaran menggunakan lab firtual.

3. Masih kurangnya dukungan orang tua wali serta belum terbukanya pola pikir siswa tentang tingginya kompetisi/ persaingan hidup diera mereka kedepannya (era melinial), sehingga mereka masih merasa aman dan nyaman dengan kondisi saat ini.
Akibatnya motivasi mereka untuk selalu haus akan ilmu serta mengejar pendidikan lanjut ke perguruan tinggi masih belum terbangun.

Berdasarkan tiga permasalahan yang dihadapi oleh mitra (MA Al-Istiqomah NW Bedus) di atas, maka kami tim pengabdian akan mencoba menyelesaikan, memberikan dan menawarkan solusi untuk mengatasi permasalahan-permasalahan tersebut, terutama poin 1 dan 2. Adapun solusi tersebut yaitu melalui pendekatan dari guru-guru MA Al-Istiqomah NW Bedus, untuk dilaksanakan dan diteruskan ke siswa-siswa mereka secara berkelanjutan. Solusi tersebut yaitu "Pelatihan Pembuatan Media atau Video Pembelajaran untuk Guru MA Al-Istiqomah NW Bedus". Menurut Dwijayani (2019) Kegiatan pelatihan dapat memberkan dampak positif untuk guru karena dinilai mampu memberikan pengetahuan yang lebih untuk membuat media pembelajaran.

Bersama mitra dan Guru-guru MA AlIstiqomah NW Bedus sebagai unit percontohan memiliki target dengan tujuan utama selain pemberian motivasi sekaligus transfer ilmu berupa pelatihan media, agar kedepannya guru-guru (target) pada saat mengajar materi tidak hanya dengan ceramah sambil bercerita saja, tapi dilengkapi dengan media, audio dan video yang membuat peserta didik lebih tertarik dan termotivasi untuk belajar.

\section{METODE PELAKSANAAN}

Pengabdian "Pelatihan Pembuatan Media atau Video Pembelajaran untuk Guru MA Al-Istiqomah NW Bedus" ini, penting untuk dilaksanakan mengingat mitra sangat membutuhkan peningkatan kompetensi gurugurunya dalam menyusun media pembelajaran. Dalam pelaksanaan program ini, ada beberapa langkah/tahapan yang direncanakan sebagai solusi dari permasalahan yang ada yaitu:

1. Tahap Pemetaan dan Analisis Awal Kesiapan Mitra. Dalam tahap ini dilakukan pemetaan dan analisis permasalahan dan kebutuhan mitra dalam meningkatkan kompetensi guru, siswa, dan daya saing dari MA Al-Istiqomah NW Bedus.

2. Tahap Inisiasi Pelaksanaan Program. Tahap inisiasi ini akan dilakukan dengan melakukan pertemuan antara tim pengabdian dengan mitra untuk menjelaskan siapa saja pesertanya, pengaturan jadwal pelaksanaan pelatihan sehingga pelaksanaan pelatihan tidak menyebabkan terbengkalainya kegiatan belajar mengajar sebagaimana mestinya. Kegiatan inisiasi ini juga dilakukakan untuk mempersiapkan sarana penunjang 
berupa komputer, LCD, serta sofwersofwer yang diperlukan untuk pelatihan.

3. Tahap Pelatihan Pembuatan Media/Video Pembelajaran. Pada Tahap ini pelatihan langsung yang diikuti oleh guru-guru MA Al-Istiqomah NW Bedus, serta peserta lainnya yang direkomendasikan oleh Kepala MA Al-Istiqomah NW Bedus dengan jumlah peserta maksimal 20 orang.

4. Pendampingan dan Pemberdayaan Lebih Lanjut. Tentunya kegiatan pelatihan ini tidak berhenti sampai disini akan tetapi akan terus dijalin kerjasama yang berkesinambungan yang menguntungkan kedua belah pihak.

5. Tahap Evaluasi. Pada tahap ahir pelatihan diberikan angket respon keinginan peserta terhadap kegiatan yang dilaksnakan dengan indikator keberhasilan (Nofisulastri dkk, 2013) , yaitu:

- lebih dan $75 \%$ peserta yang diundang selalu hadir dalam setiap kegiatan

- lebih dari $90 \%$ peserta yang hadir menyatakan kegiatan ini bermanfaat

\section{HASIL DAN PEMBAHASAN}

Kegiatan pengabdian kepada masyarakat bertajuk pelatihan pembuatan media video pembelajran untuk guru MA Alistiqomah NW Bedus telah dilaksanakan pada tanggal 18 September 2019. Pelaksanaan kegiatan pengabdian masyarakat ini diawali survei lokasi sekaligus diskusi penjadwalan kegiatan dan MOu oleh tim bersama mitra yaitu MA Al-istiqomah NW Bedus. Target binaan adalah guru Al-istiqomah NW Bedus sejumlah 20 orang yang selama mengajar jarang bahkan tidak pernah menggunakan media video dalam melaksanakan pembelajaran di sekolah.

Kegiatan pelatihan didampingi oleh kepala sekolah (Sayuti Arja, S.Pd.I.) dan 2 orang mahasiswa Pendidikan Fisika FPMIPA IKIP Mataram sebagai pendamping kegiatan dan tim promo perguruan tinggi. Kegiatan pelatihan dilaksanakan selama satu hari dari jam 10.00 samapi 13,00. Agenda pelatihan meliputi sambutan pihak sekolah (mitra), penayangan video promosi IKIP Mataram, sosialisasi kegiatan, pengenalan contoh media video pembelajaran, pelatihan pembuatan media dan diskusi. Hasil dalam tahapan dalam kegiatan ini berupa responsif peserta dengan melihat banyaknya pertanyaan berisikan ketertarikan kegiatan yang dipaparkan dan antusias peserta terhadap kegiatan yang akan mereka laksanakan.

Kegiatan pelatihan meliputi penayangan media video pembelajaran penyampaian materi secara bertahap yang langsung dicoba oleh setiap peserta di laptope masing-masing, pendampingan oleh tim tutor dan diakhiri dengan pemberian respon kegiatan sambil makan siang bersama.

Dampak kegiatan dari tahap sosialisasi hingga tahap pelatihan dianalisis menggunakan lembar kuisoner/angket respon kegiatan. Item penilaian terdiri atas sejauhmana kebermanfaatan kegiatan bagi binaan, ketertarikan terhadap prosesi pelaksanaan kegiatan, dan motivasi untuk menjadi guru yang modern (dalam arti mau membuat dan mengajar dengan media). Hasilnya, lebih $90 \%$ kehadiran peserta datang tepat waktu dan berada dalam ruangan hingga kegiatan berakhir. Respon kebermanfaatan kegiatan pelatihan meliputi sebesar 85,0 \% (kategori sangat bagus) dan $15,0 \%$ berkategori cukup bagus; dan tingkat motivasi menjadi guru modern sebesar 80,0 \% tertarik dan 20,0\% berkategori cukup.

Berdasarkan tujuan dan target kegiatan pengabdian pada msayarakat yaitu mengembangkan kompetensi dan kemampuan guru-guru MA Al-Istiqomah NW Bedus untuk membuat media/video pembelajaran, maka luaran yang telah tercapai berupa adanya transfer keterampilan/skills berupa produk nata, kerjasama secara kontinu terhadap mitra baik pengabdian maupun penelitian.

\section{KESIMPULAN}

Dampak kegiatan pengabdian menunjukkan bahwa keberhasilan terukur lebih 90\% kehadiran peserta datang tepat waktu dan responsive terhadap kebermanfaatan kegiatan terukur sangat bagus serta adanya harapan keberlanjutan pelatihan bagi guru MA Al-Istiqomah NW Bedus

\section{DAFTAR RUJUKAN}

Arief Sadiman, dkk. (2009). Media Pendidikan Pengertian, Pengembangan, dan Pemanfaatannya. Jakarta: PT. Raja Grafindo Persada.

Arsyad Azhar. (2007). Media Pembelajaran. Jakarta: PT Raja Grafindo Persada

Indriyanti, Ririn. (2017). "Pengembangan Media Powerpoint Interaktif" Skripsi: universitas Sanata Darma Yogyakarta.

Nofisulastri, Any Fatmawati,Sucika Armiani. (2018). "Pelatihan Pembuatan Nata de Coco dan Nata de Soya Bersama Siswi Kelas XI di MA. Annajah Yayasan 
Pendidikan Al-Halimy". Lumbung Inovas, 3(1). 87-92.

Tim Penyusun. (2019). "Modul Jago Bikin Media Powerpoint". Disampaikan pada pelatiahan pembuatan media/video pembelajaran IKIP Mataram.

Dwijayani Ni Made, dkk., (2019). "Peningkatan Keterampilan Pembuatan Media Pembelajaran di SD No. 1 Kapal". Jurnal Selaparang, 3(1), 64-70. 